\title{
Hypertrophic pulmonary osteoarthropathy and its occurrence with pulmonary metastases from renal carcinoma
}

\author{
P. G OLDSTRA W a d P. R. W A L B A U M \\ Thoracic Surgery Unit, City Hospital, Edinburgh EH10 5SB
}

\begin{abstract}
Goldstraw, P. and Walbaum, P. R. (1976). Thorax, 31, 205-211. Hypertrophic pulmonary osteoarthropathy and its occurrence with pulmonary metastases from renal carcinoma. The literature of hypertrophic pulmonary osteoarthropathy is reviewed with special reference to its occurrence with pulmonary metastases from extrathoracic tumours. The present theories on aetiology are discussed, and the relationship to finger clubbing and bronchogenic carcinoma is reviewed.

A case is reported of hypertrophic osteoarthropathy as the presenting feature of pulmonary metastases from renal carcinoma, and of its relief by pulmonary resection.
\end{abstract}

Hypertrophic pulmonary osteoarthropathy was first described at the end of the 19th century independently by Bamberger (1889) and Marie (1890) and is still often referred to as the MarieBamberger syndrome in continental literature. These original articles described the syndrome in association with chronic pulmonary inflammatory disease, and it was 15 years later before it was first reported as occurring with carcinoma of the bronchus (Thompson, 1904). Indeed it had been reported associated with pulmonary metastases some nine years earlier (Virchow, 1895).

Many other tumours and disorders have since been reported in association with hypertrophic osteoarthropathy (Table I). It has also been reported occurring with successive pregnancies, and an idiopathic form has also been described. However, with the increasing incidence of bronchogenic carcinoma this has become by far the commonest cause of hypertrophic osteoarthropathy, and many reference books now omit pulmonary metastases from their list of conditions known to be associated with the syndrome (Crofton and Douglas, 1969; Cecil and Loeb, 1963).

Excellent reviews by Yacoub, Simon, and

T A B L E I

CONDITIONS ASSOCIATED WITH HYPERTROPHIC OSTEOARTHROPATHY

\begin{tabular}{|c|c|c|c|}
\hline Condition & Site & Author & Year \\
\hline $\begin{array}{l}\text { Chronic sepsis } \\
\text { Carcinoma } \\
\text { Adeno carcinoma } \\
\text { Leiomyoma } \\
\text { Hodgkin's disease } \\
\text { Chronic myeloid } \\
\text { leukaemia } \\
\text { Fibroma } \\
\text { Cyanotic congenital } \\
\text { heart disease } \\
\text { Graves disease } \\
\text { Achalasia } \\
\text { Peptic ulceration } \\
\text { Portal cirrhosis } \\
\text { Successive pregnancies } \\
\text { Idiopathic familial }\end{array}$ & 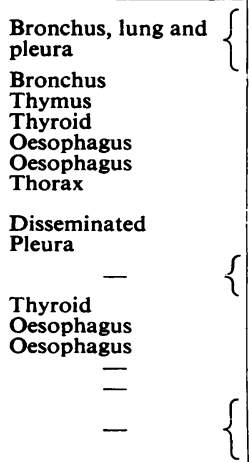 & $\begin{array}{l}\text { Bamberger } \\
\text { Marie } \\
\text { Locke } \\
\text { Thompson } \\
\text { Miller } \\
\text { Richards } \\
\text { Carroll and Doyle } \\
\text { Ullal } \\
\text { Shapiro and Zvaifler } \\
\text { Temple and Jaspin } \\
\text { Thomas and Drew } \\
\text { Kahn } \\
\text { Trever } \\
\text { Danforth and Humphrey } \\
\text { Naish } \\
\text { Carroll and Doyle } \\
\text { Buchan and Mitchell } \\
\text { Cullen and Maskery } \\
\text { Angel } \\
\text { Baldwin } \\
\text { Hecht }\end{array}$ & $\begin{array}{l}1889 \\
1890 \\
1915 \\
1904 \\
1939 \\
1971 \\
1974 \\
1972 \\
1973 \\
1948 \\
1953 \\
1957 \\
1958 \\
1958 \\
1959 \\
1974 \\
1967 \\
1966 \\
1957 \\
1959 \\
1965\end{array}$ \\
\hline
\end{tabular}


Ohnsorge (1967), Aufses and Aufses (1960), and Alexander and Johnson (1962) have recorded primary tumours the pulmonary metastases from which have been associated with hypertrophic osteoarthropathy (Table II). These include various sarcomata, carcinomata, and melanoma. To these may now be added renal carcinoma.

\section{CASE REPORT}

In February 1972, a 70-year-old woman, a nonsmoker, underwent nephrectomy for a carcinoma of the lower pole of the left kidney without histological evidence of extracapsular extension. At that time she had no respiratory or locomotor symptoms, and her chest radiograph was normal. She made a good postoperative recovery and remained well for two and a half years.

In September 1974, the patient was readmitted to hospital complaining of pain in both wrists and both ankles. There was marked finger clubbing, which her general practitioner had noted to be of recent onset, the wrists and ankles were swollen, tender, and warm, and there was marked oedema of both ankles. She denied any respiratory symptoms. A chest radiograph (Fig. 1) showed a 4-cm. round opacity in the apical segment of the right lower lobe. Limb radiographs showed symmetrical marked subperiosteal new bone formation in the distal shafts of the radius, ulna (Fig. 2), tibia, and fibula.

These bony changes and the symptomatology were typical of hypertrophic pulmonary osteoarthropathy. The pulmonary opacity was thought to be a primary carcinoma of the bronchus.

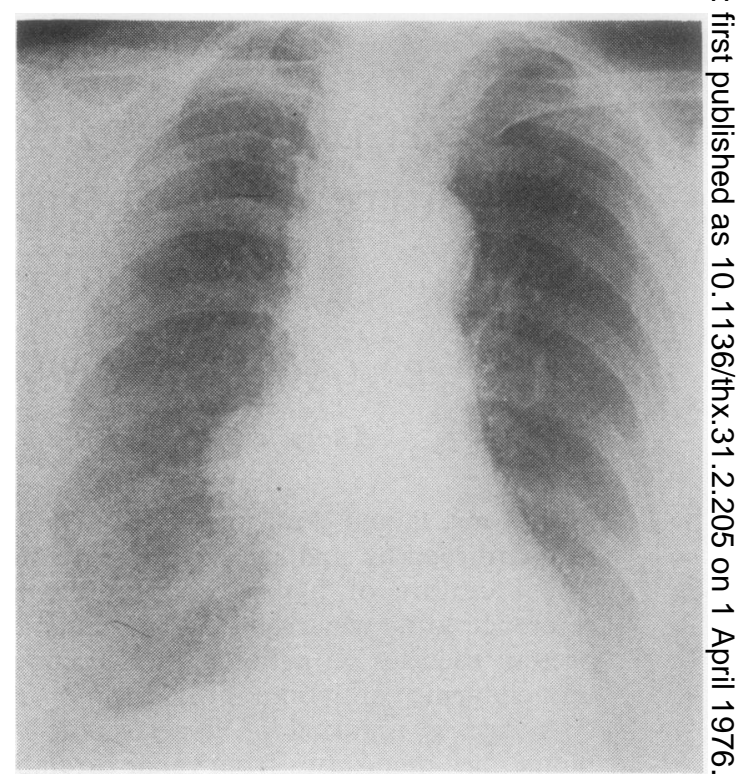

FIG. 1. Chest radiograph September 1974, showing opacity in apical segment of right lower lobe.

At right thoracotomy, there were, in addition to the apical lower mass, two nodules in the basalo segments, each $1-2 \mathrm{~cm}$ in diameter. All palpable $\overrightarrow{\vec{O}}$ tumour was removed by lower lobectomy and the $\exists$ patient made an uneventful recovery. Histological examination revealed the lesions to be metastases from a renal carcinoma (Fig. 3).

The patient's joint pains disappeared com-음 pletely immediately following resection, and the radiological changes in the limbs have regressed.

T A B L E I I

TUMOURS FROM WHICH PULMONARY METASTASES HAVE BEEN ASSOCIATED WITH HYPERTROPHIC OSTEOARTHROPATHY

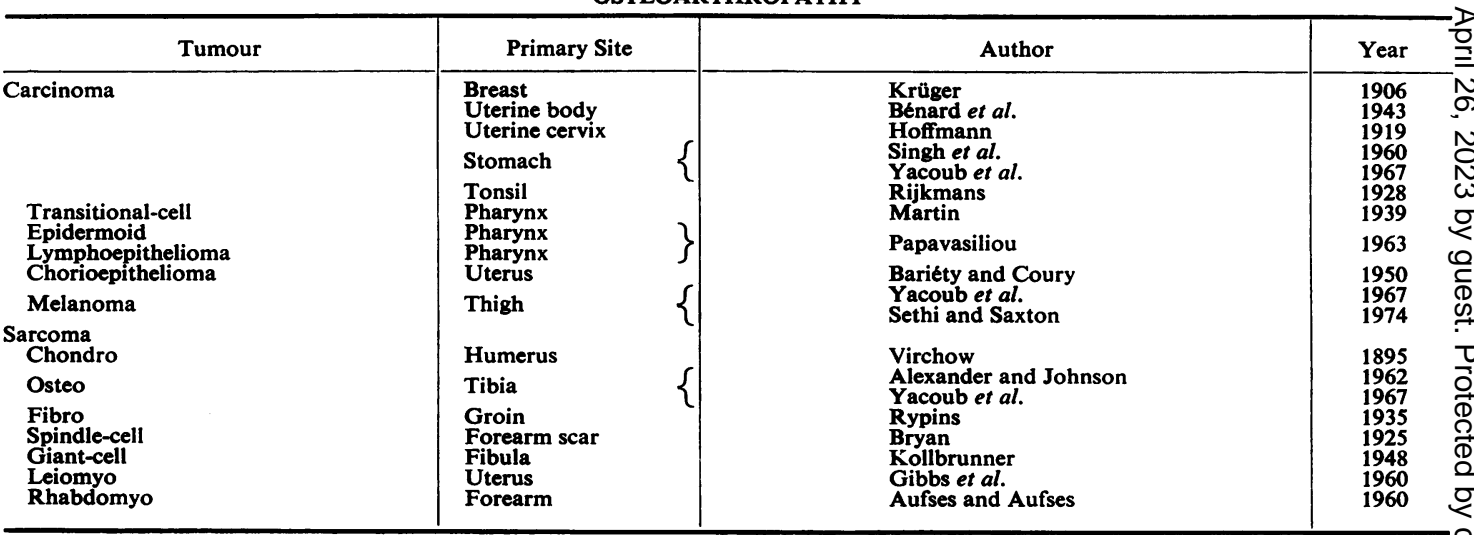




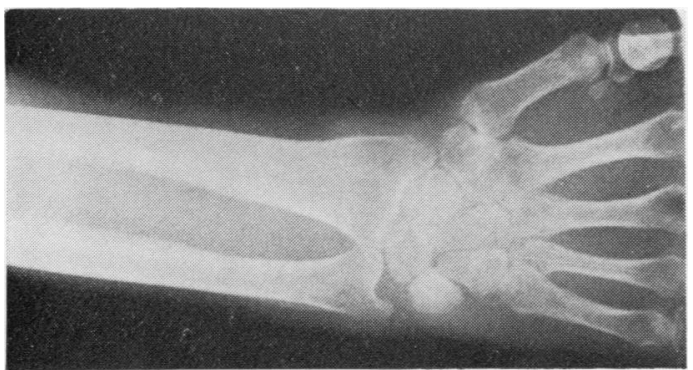

FIG. 2. Radiograph of wrist showing subperiosteal new bone on distal shaft of ulna.

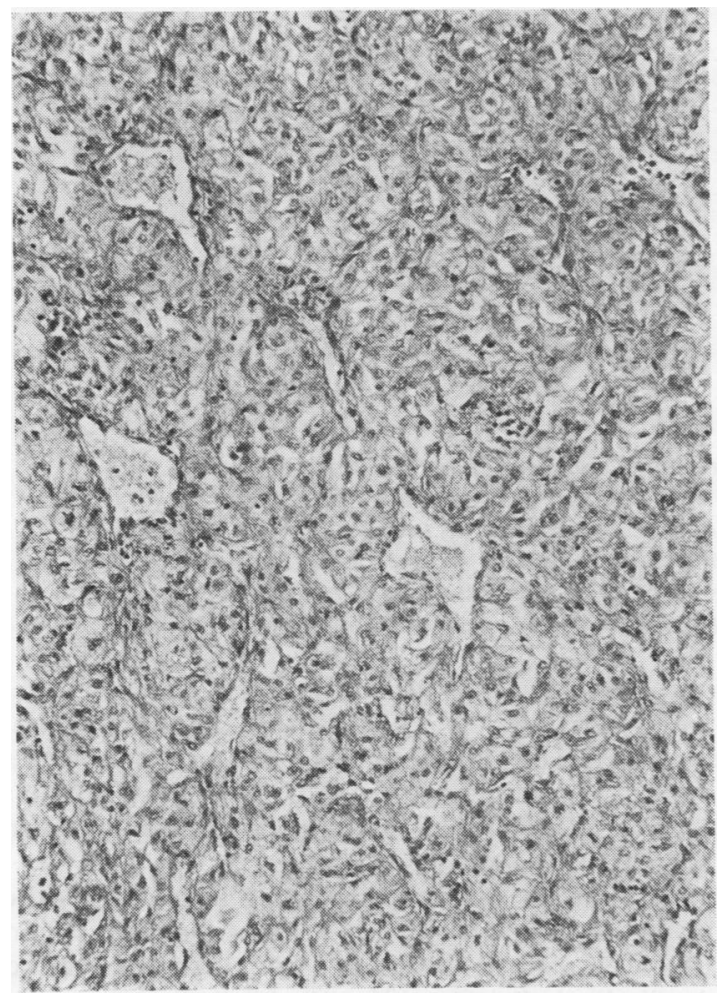

FIG. 3. Histology of pulmonary tumour. The large clear cells wih central nuclei are typical of renal carcinoma $(H$ and $E \times 75)$.

The wrist radiographs are now normal but a thin line of persisting periosteal new bone is still visible on radiographs of the ankles. The finger clubbing has persisted.

She remained well and symptom free for six months but has recently developed signs of cerebral metastases.

\section{DISCUSSION}

ASSOCIATION WITH FINGER CLUBBING In our patient clubbing of the fingers was marked and its recent appearance first alerted the general practitioner to the possibility of a pulmonary aetiology for the arthropathy. However, in reviewing the literature, we encountered confusion and differences in opinion regarding the relationship between hypertrophic osteoarthropathy and clubbing of the fingers.

Some authors consider the two conditions to be aetiologically linked and regard the latter as an earlier, less severe manifestation of the former (Berman, 1963; Locke, 1915; Mendlowitz, 1942). Others use the term synonymously and consider the two essential for the syndrome (Bartter, 1963; Leading Article, 1959). Still others regard the two conditions as separate entities while allowing that finger clubbing is 'usually present' (Yacoub et. al., 1967), 'present in most cases' (Holling and Brodey, 1961), or 'almost always present' (Aufses and Aufses, 1960) in hypertrophic osteoarthropathy. In our experience finger clubbing is invariably present.

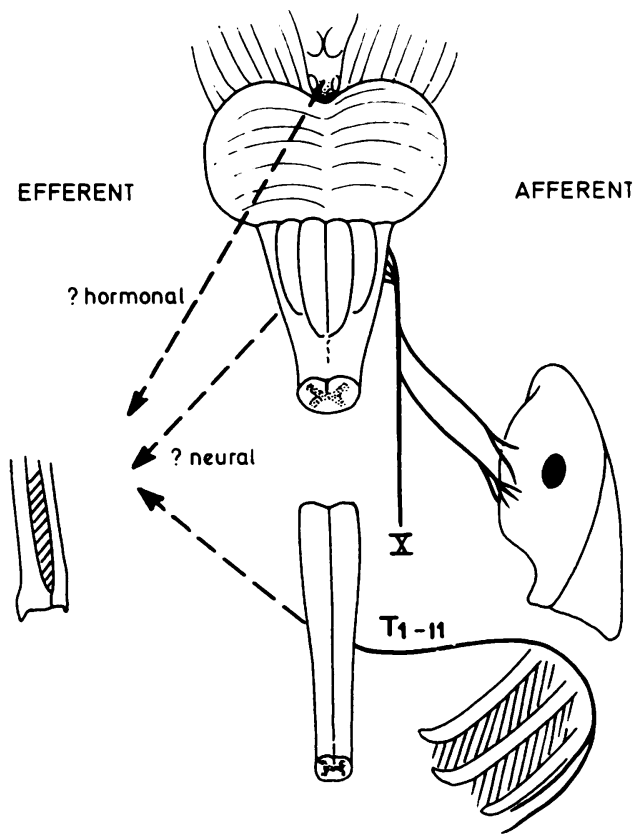

FIG. 4. The neuronal theory of hypertrophic pulmonary osteoarthropathy suggests that afferent impulses originating in the pulmonary focus travel via the vagus or intercostal nerves to the central nervous system, The efferent mechanism is conjectural and may be hormonal or neural. 


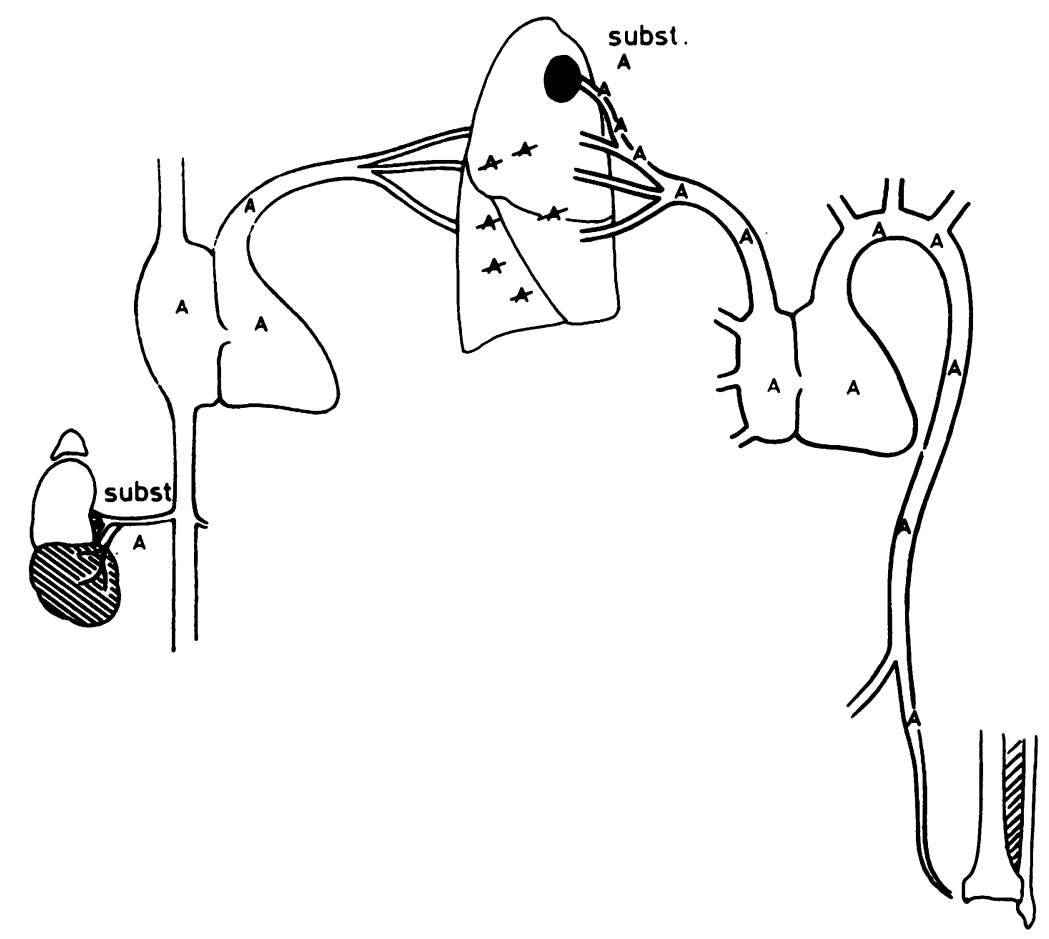

FIG. 5. The hormonal theory of hypertrophic pulmonary osteoarthropathy. Substance $A$ is capable of stimulating new bone formation and is produced by the tumour (shown here in kidney) and its pulmonary metastases. Any of substance $A$ passing through the pulmonary circulation is inactivated, and hence only primary pulmonary tumours or pulmonary metastases can release the active substance into the systemic circulation causing hypertrophic osteoarthropathy.

Skorneck and Ginsburg (1958) argued that the occurrence of clubbing with pulmonary tuberculosis and the great rarity of hypertrophic osteoarthropathy in the same condition is against common aetiology or single syndrome. This argument would find little support in this country where the experience of most surgeons would suggest that clubbing in uncomplicated pulmonary tuberculosis is at least as rare as the occurrence of hypertrophic osteoarthropathy in that condition. Holling and Brodey (1961) put forward a similar argument using cyanotic congenital heart disease as an illustration.

\section{AETIOLOGY OF HYPERTROPHIC OSTEOARTHROPATHY} At present three theories are proposed.

Neuronal Theory (Fig. 4) Flavell (1956) suggested a neuronal mechanism, a theory supported by the experimental work of Holling (1967), Holling, Brodey, and Boland (1961), and Holling et al. (1963). These workers believe that afferent im pulses travel via the vagus or intercostal nerves from the pulmonary focus to the central nervous system. The efferent pathway is totally unknowns and may be hormonal or neural.

In the experiments by Holling et al. (1963) the effect of thoracotomy and various manoeuvres ord the lung and mediastinum in dogs was monitore by limb plethysmography. Only dissection in the mediastinum or blocking of the vagus nervew produced any recordable and reproducible effect on limb blood flow, a parameter assumed too bear a direct relationship to hypertrophices osteoarthropathy.

In humans, regression of arthropathy has been reported after cervical or superior mediastina $P_{D}$ vagotomy (Flavell, 1956) and following transec $\Omega$ tion of intercostal nerves (Hollman, 1963).

Carroll and Doyle (1974) have also suggested reflex arc and noted the area of the primaryo 
disease to be served by the ninth or tenth cranial nerves.

Hormonal Theory (Fig. 5) The hormonal theory was proposed by Marie (1890) in his original description and has since been expanded to suggest that some tumours produce a hormone-like substance or toxin capable of stimulating periosteal new growth. It is suggested that this substance is normally inactivated by passage through the lungs, and hence only primary lung tumours and pulmonary metastases release the substance into the systemic circulation and produce hypertrophic osteoarthropathy. Cross perfusion experiments for short periods by Holling et al. (1961) have failed to produce hypertrophic osteoarthropathy or changes in limb blood flow.

The only direct evidence of hormonal imbalance in osteoarthropathy is that of Ginsburg and Brown (1961). These workers found the urinary excretion of oestrogen derivatives in males with hypertrophic osteoarthropathy and bronchogenic carcinoma to be double that of controls. The controls included healthy males, males with broncho- genic carcinoma but without arthropathy, and males with gynaecomastia from other causes. The elevated levels returned to normal within weeks of operation.

$A-V$ Shunt Theory (Fig. 6) This third theory is a development of the hormonal theory and proposes that normal tissues, arbitrarily shown as bone marrow, kidney, and spleen, produce a hormone-like substance capable of stimulating periosteal new growth, that this substance is inactivated in the pulmonary circulation, and that in certain conditions and tumours the development of pulmonary arteriovenous shunts allows escape of these substances into the systemic circulation with resultant hypertrophic osteoarthropathy (Cudkowicz and Armstrong, 1953).

Attempts artificially to produce such shunts have proved difficult, but in one dog, in which the pulmonary artery was anastomosed to the left auricular appendage, hypertrophic osteoarthropathy was produced (Mendlowitz and Leslie, 1942).

This theory explains the occurrence of osteo-

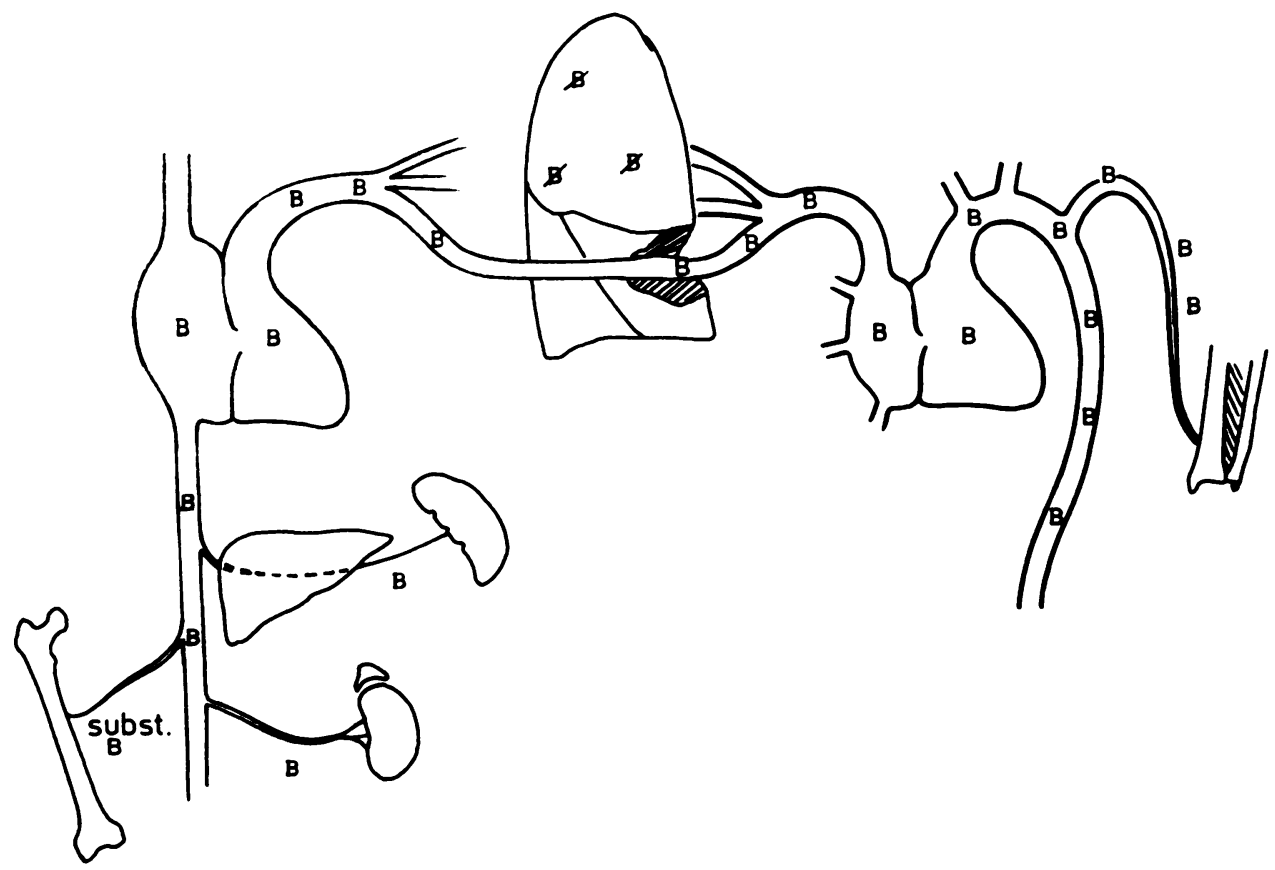

FIG. 6. The A-V shunt theory of hypertrophic pulmonary osteoarthropathy. Substance B is capable of stimulating new bone formation and is produced by normal tissues (here arbitrarily shown as spleen, kidney, and bone marrow). Passage through the lungs inactivates substance $B$, but in certain tumours and conditions arteriovenous shunts develop within the lung and allow escape of substance $B$ into the systemic circulation with consequent hypertrophic osteoarthropathy. 
arthropathy in congenital cyanotic heart disease where such shunts are known to exist.

Yacoub et al. (1967) point out that hypertrophic osteoarthropathy is exceedingly rare in the vascular oat-cell carcinoma but common in many avascular fibrous tumours, finding its highest incidence $(60 \%)$ in pleural fibroma (Thomas and Drew, 1953).

INCIDENCE The incidence of hypertrophic pulmonary oseoarthropathy in bronchogenic carcinoma is reported to be from 0 to $10 \%$ (Table III), probably due to the varying criteria required in each study for the diagnosis of osteoarthropathy, and the diligence with which the condition is sought.

We have never before encountered this condition associated with pulmonary metastases, and indeed the world literature totals less than 50 cases.

However, it would seem prudent in the presence of a pulmonary opacity, a history of previous malignancy, and hypertrophic osteoarthropathy to perform more detailed investigations before assuming the opacity to be a new primary. These investigations we feel should include total lung tomography to exclude multiple pulmonary lesions, and radio-isotopic scanning of liver, brain, and skeleton to exclude any extrapulmonary metastases.

T A B L, E I I I

INCIDENCE OF HYPERTROPHIC OSTEOARTHROPATHY IN BRONCHOGENIC CARCINOMA

\begin{tabular}{c|l|c}
\hline $\begin{array}{c}\text { Per cent } \\
\text { Incidence }\end{array}$ & \multicolumn{1}{|c}{ Author } & Year \\
\hline 0 & Aufses and Aufses & 1960 \\
$1-2$ & Semple and McCluskie & 1955 \\
4 & Yacoub et. al. & 1967 \\
$5 \cdot 2$ & Jack & 1953 \\
& Flavell & 1956 \\
\hline
\end{tabular}

We should like to thank Dr. A. G. Reid, the patient's general practitioner, for invaluable help in making available notes and radiographs.

\section{REFERENCES}

Alexander, C. P. and Johnson, V. W. (1962). Hypertrophic pulmonary osteoarthropathy associated with pulmonary metastases removed surgically. Postgraduate Medical Journal, 38, 173

Angel, J. H. (1957). Pachydermo-periostosis (idiopathic osteoarthropathy). British Medical Journal, 2, 789.
Aufses, A. H. and Aufses, B. H. (1960). Hypertrophic osteoarthropathy in association with pulmonary metastases from extrathoracic malignancies. Diseases of the Chest, 38, 399.

Baldwin, J. N. (1959). Idiopathic hypertrophic osteo- $\frac{\widehat{T}}{D}$ arthropathy. New England Journal of Medicine, $₫$ 261, 592.

Bamberger, E. (1889). A case report (German). Wiener klinische Wochenschrift, 2, 226.

Bariéty, M. and Coury, C. (1950). L'ostéo-arthropathie $\vec{\omega}$ hypertrophiante pneumique et les dysacromélies d'origine thoracique. Semaine des Hôpitaux de $\overrightarrow{\vec{x}}$ Paris, 26, 1681.

Bartter, F. C. (1963). Hypertrophic pulmonary osteo- $\frac{\omega}{-}$ arthropathy. In Cecil-Loeb Textbook of Medi-N cine, edited by P. B. Beeson and W. McDermott. O Saunders, Philadelphia.

Bénard, H., Rambert, P., Deparis, M., and Péstel, P. 은 (1943). Osteoarthropathic pneumique et cancer du poumon. Bulletins et Mémoires de la Société $\frac{}{2}$ Médicale des Hôpitaux de Paris, 59, 132.

Berman, B. (1963). Pulmonary hypertrophic osteoarthropathy. Archives of Internal Medicine, 112, 947.

Bryan, L. (1925). Secondary hypertrophic osteoarthropathy following metastatic sarcoma of the lung. California and Western Medicine, 23, 449.

Buchan, D. J. and Mitchell, D. M. (1967). Hypertro- ֶ̊ phic osteoarthropathy in portal cirrhosis. Annals of Internal Medicine, 66, 130.

Carroll, K. B. and Doyle, L. (1974). A common factor in hypertrophic osteoarthropathy. Thorax, 29, 262.

Cecil, R. L. and Loeb, R. F. (1963). Hypertrophic osteoarthropathy. In Cecil-Loeb Textbook of Medicine, edited by P. B. Beeson and W. 음 McDermott, 11 th edition. Saunders, Philadelphia.

Crofton, J. and Douglas, A. (1969). Hypertrophic osteoarthropathy. In Respiratory Diseases, p. 533. Blackwell, Oxford.

Cudkowicz, L. and Armstrong, J. B. (1953). Finger clubbing and changes in the bronchial circulation: arterio-venous shunts in hypertrophic pul- $\triangle$ monary osteoarthropathy. British Journal of $\frac{D}{O}$ Tuberculosis, 47, 227.

Cullen, D. R. and Maskery, P. J. K. (1966). Clubbing of the fingers and hypertrophic osteoarthropathy in pregnancy. Lancet, $1,473$.

Danforth, W. H. and Humphrey, H. A. (1958). Hyper- N trophic osteoarthropathy and pretibial myxedema associated with Graves' disease. Journal of Clinical Endocrinology, 18, 1302.

Flavell, G. (1956). Reversal of pulmonary hypertro- $\mathbb{D}$ phic osteoarthropathy by vagotomy. Lancet, $1, \stackrel{+}{+}$ 260.

Gibbs, D. D., Schiller, K. F. R., and Stovin, P. G. I. (1960). Lung metastases heralded by hypertrophic pulmonary osteoarthropathy. Lancet, 1, 623.

Ginsburg, J. and Brown, J. B. (1961). Increased $\frac{\varrho}{\sigma}$ oestrogen excretion in hypertrophic pulmonary osteoarthropathy. Lancet, 2, 1274. 
Hecht, A. (1965). Idiopathic hypertrophic osteoarthropathy. New York Journal of Medicine, 65, 3038.

Hoffmann, V. (1919). Ein Beitrag zur Kenntnis der Osteoarthropathie hypertrophiante pneumique. Deutsches Archiv für klinische Medizin, 130, 201.

Holling, H. E. (1967). Editorial note. Annals of Internal Medicine, 66, 232.

and Brodey, R. S. (1961). Pulmonary hypertrophic osteoarthropathy. Journal of the American Medical Association, 178, 977.

,-- , and Boland, H. C. (1961). Pulmonary hypertrophic osteoarthropathy. Lancet, 2, 1269.

- - Danielson, G. K., Hamilton, R. W., Blakemore, W. S., and Brodey, R. S. (1963). Hypertrophic pulmonary osteoarthropathy. Journal of Thoracic and Cardiovascular Surgery, 46, 310.

Hollman, C. W. (1963). Osteoarthropathy in lung cancer: disappearance after section of intercostal nerves. Journal of Thoracic and Cardiovascular Surgery, 45, 679.

Jack, G. D. (1953). Bronchogenic carcinoma. Transactions of the Medico-Chirugical Society of Edinburgh, 132 (in Edinburgh Medical Journal, 60), 75.

Kahn, D. (1957). Clubbing and hypertrophic osteoarthropathy. Archives of Internal Medicine, 100, 147.

Kollbrunner, F. (1948). Gutartiger Riesenzelltumor mit maligner Entartung nach vier Jahren und Ostéoarthropathie hypertrophiante pneumique durch Lungenmetastase. Oncologia, 1, 153.

Krüger (1906). Zur Kenntis der Ostéoarthropathie hypertrophiante pneumique. Virchows Archiv für pathologische Anatomie und Physiologie und für klinische Medizin, 185, 43.

Leading article (1959). Clubbing of the fingers and osteoarthropathy. Lancet, 2, 390.

Locke, E. A. (1915). Secondary hypertrophic osteoarthropathy and its relationship to simple clubfingers. Archives of Internal Medicine, 15, 659.

Marie, P. (1890). De l'ostéo-arthropie hypertrophiante pneumique. Revue de Medecine, 10, 1 .

Martin, C. L. (1939). Complications produced by malignant tumors of the nasopharynx. American Journal of Roentgenology, 41, 377.

Mendlowitz, M. (1942). Clubbing and hypertrophic osteoarthropathy. Medicine, 21, 269.

tion in the dog of the cyanosis and hypertrophic osteoarthropathy which are associated with congenital heart disease. American Heart Journal, 24, 141.

Miller, E. R. (1939). Carcinoma of the thymus, with marked pulmonary osteo-arthropathy. Radiology, 32, 651.

Naish, J. (1959). Achalasia of cardia and osteoarthropathy. British Medical Journal, 1, 365.

Papavasiliou, C. G. (1963). Pulmonary metastases from cancer of the nasopharynx associated with hypertrophic osteoarthropathy. British Journal of Radiology, 36, 680.

(1968). Intrathoracic spread of nasopharyngeal cancer. Cancer (Philadelphia), 21, 940.

Richards, A. J. (1971). A case of thyroid carcinoma and primary hyperparathyroidism with pseudoclubbing. British Journal of Clinical Practice, 25, 34 .

Rijkmans, J. C. (1928). Bijdrage tot de kennis van de acropachie. Dissertation de Waal, Groningen.

Rypins, E. L. (1935). Hypertrophic osteo-arthropathy. Radiology, 25, 289.

Semple, T. and McCluskie, R. A. (1955). Generalised hypertrophic osteoarthropathy in association with bronchial carcinoma. British Medical Journal, 1, 754.

Sethi, S. M. and Saxton, G. D. (1974). Osteoarthropathy associated with solitary pulmonary metastasis from melanoma. Canadian Journal of Surgery, 17, 221.

Shapiro, R. F. and Zvaifler, N. J. (1973). Concurrent intrathoracic Hodgkin's disease and hypertrophic osteoarthropathy. Chest, 63, 912.

Singh, A., Jolly, S. S., and Bansal, B. B. (1960). Hypertrophic osteoarthropathy associated with carcinoma of the stomach. British Medical Journal, 2, 581

Skorneck, A. B. and Ginsburg, L. B. (1958). Pulmonary hypertrophic osteoarthropathy (periostitis): its absence in pulmonary tuberculosis. New England Journal of Medicine, 258, 1079.

Temple, H. L. and Jaspin, G. (1948). Hypertrophic osteoarthropathy. American Journal of Roentgenology, 60, 232.

Thomas, C. P. and Drew, C. E. (1953). Fibroma of the visceral pleura. Thorax, 8, 180.

Thompson, H. E. S. (1904). Hypertrophic pulmonary osteo-arthropathy. Medico-Chirurgical Transactions, 87, 85 .

Trever, R. W. (1958). Hypertrophic osteoarthropathy in association with congenital cyanotic heart disease: report of two cases. Annals of Internal Medicine, 48, 660.

Ullal, S. R. (1972). Hypertrophic osteoarthropathy and leiomyoma of the esophagus. American Journal of Surgery, 123, 356.

Virchow, R. (1895). Veränderungen des Skelets durch Akromegalie. Berliner klinische Wochenschrift, 32, 1102 .

Yacoub, M. H., Simon, G., and Ohnsorge, J. (1967). Hypertrophic pulmonary osteoarthropathy in association with pulmonary metastases from extrathoracic tumours. Thorax, 22, 226.

Requests for reprints to: P. Goldstraw, FRCS, Thoracic Surgery Unit, City Hospital, Edinburgh EH10 5SB. 